\title{
Analisis Ketepatan Koding Dan Kinerja Petugas Di Unit Koding-Indeksing Rumah Sakit Mitra Husada Kota Pring Sewu
}

\author{
Faik Agiwahyuanto ${ }^{1 *}$, Tri Indah Sari ${ }^{2}$, dan Shinta Octaviasuni ${ }^{3}$ \\ ${ }^{1,2,3}$ Dosen Program Studi D-3 Rekam Medis dan Informasi Kesehatan, Fakultas Kesehatan, \\ Universitas Dian Nuswantoro Semarang \\ Email: ${ }^{1}$ faik.agiwahyuanto@dsn.dinus.ac.id
}

\begin{abstract}
The unit coding in Mitra Husada Hospital in determining the diagnosis and action codes still usess manual because of the unavailability uses the ICD-10 to determine the diagnostic code and ICD-9 CM to determine the action code. In addition, there are only 2 people coding staff. The research objective is to determine the implementaion and perfomance of coding and indexing officers at Mitra Husada Hospital. The research methode uses and explanatory design or sequantial transformative strategy. The population are 100 coding cases of hospitalizatioan at Mitra Husada Hospital. The sample are 30 coding cases of hospitalization. Informative informants are 2 coding and indexing officers. Data collection of qualitative and quantitative data analysis. The results show that the coding section already has a code suitability 100\%. Implementation of coding officers still need to learn MB rules and the basic causes of death in order to increase already has an SPO which has not run according to the implementaion carried out by the officer. The mixing of the coding and indexing procedures which in its implementaion was carried out separately so as to indicate the non-compliance of officers againts the SPO in the coding and indexing units.
\end{abstract}

Keywords: coding, indexing, performence

\begin{abstract}
Abstrak
Bagian unit koding di RS Mitra Husada dalam menentukan kode diagnosis dan tindakan masih menggunakan koding manual karena belum tersedianya ICD elektronik. Penentuan kode menggunakan ICD-10 untuk menentukan kode diagnosa dan ICD-9 CM untuk mementukan kode tindakan. Selain itu, petugas koding hanya ada 2 orang. Tujuan penelitian untuk mengetahui pelaksanaan dan kinerja petugas koding dan indeksing di RS Mitra Husada. Metode penelitian menggunakan desain exploratory design atau strategi transformatif sekuential. Populasi adalah koding 100 kasus rawat inap di RS Mitra Husada. Sampel penelitian sebanyak 30 koding kasus rawat inap. Informan informatif adalah petugas koding dan indeksing sebanyak 2 orang. Pengumpulan data fase kualitatif dan kuantitatif. Analisis data menggunakan analisis data kualitatif dan kuantitatif. Hasil menunjukkan bahwa bagian koding sudah memiliki kesesuaian kode sebesar 100\%. Pelaksanaan koding petugas masih perlu belajar rule MB dan penyebab dasar kematian guna menambah pengetahuan petugas. Kinerja petugas unit koding indeksing sudah terdapat SPO yang mana belum berjalan sesuai dengan pelaksanaan yang dilakukan petugas. Tercampurnya prosedur koding dan indeksing yang pada pelaksanaannya dilakukan secara terpisah sehingga mengindikasi ketidak patuhan petugas terhadap SPO yang terdapat di unit koding dan indeksing.
\end{abstract}

Kata kunci: kinerja, koding, indeksing

\section{Pendahuluan}

RS.Mitra Husada adalah rumah sakit umum yang dimiliki oleh PT. Mitra Husada Bersama. PT. Mitra Husada Bersama berdiri tanggal 14 Nopember 2006, dengan Akta Notaris M Reza Berawi, SH Nomor 32, disyahkan dengan SK Menteri Hukum dan Hak Asasi Manusia Nomor W6-00001 HT 01.01-Tahun 2007.

Latar belakang berdirinya RS.Mitra Husada adalah adanya keprihatinan dari beberapa Dokter dan
Paramedis di Pringsewu dan sekitarnya akan belum terdapatnya rumah sakit di Pringsewu yang cukup representatif, padahal animo masyarakat Pringsewu cukup tinggi, di samping dari data statistik dan studi kelayakan menunjukkan bahwa penduduk Pringsewu dan sekitarnya (Tanggamus, Pesawaran dan Lampung Tengah) masih membutuhkan rumah sakit.

Rumah Sakit Mitra Husada terletak di Jalan Jend. Ahmad Yani No. 14 Pringsewu, berdiri di atas tanah 
seluas $18.918 \mathrm{~m} 2$, dengan luas bangunan12.152,585 m2. Registrasi Rumah Sakit : 1802038 dikeluarkan oleh Departemen Kesehatan Republik Indonesia pada tanggal 1 Oktober 2009. Izin Tetap Penyelenggaraan Rumah Sakit Nomor : 440/845/D.02/P/V/2015, dikeluarkan oleh Bupati Kabupaten Pringsewu pada tanggal 1 Juni 2015. Penetapan Kelas sebagai Rumah Sakit Umum dengan Klasifikasi Kelas C dengan Nomor Keputusan Menteri Kesehatan Republik Indonesia: 762/MENKES/SK/VI/2010, ditetapkan pada tanggal 24 Juni 2010, Sertifikat Akreditasi Rumah Sakit dengan Status Akreditasi lulus tingkat tingkat PARIPURNA Nomor : KARS-SERT/745/ $\mathrm{VI} / 2017$.

Pada awal operasional pelayanan meliputi rawat jalan dan rawat inap dengan 57 tempat tidur, pada tanggal 15 Januari 2009 mendapat izin dari Dinas Kesehatan Tanggamus untuk menyelenggarakan rawat inap dengan 100 tempat tidur. Pada tahun 2015 RS. Mitra Husada menyelenggarakan rawat inap dengan kpasitas tempat tidur menjadi 156 tempat tidur. Kemudian di tahun 2018, dengan adanya pembangunan gedung rawat inap baru, kapasitas tempat tidur meningkat menjadi 202 tempat tidur. RS Mitra Husada juga menjadi tempat rujukan pasien selain Rumah Sakit Umum Daerah (RSUD) Kota Lampung.

Bagian unit koding di RS Mitra Husada dalam menentukan kode diagnosa dan tindakan masih menggunakan koding manual karena belum tersedianya ICD elektronik. Penentuan kode menggunakan ICD-10 untuk menentukan kode diagnosa dan ICD-9 CM untuk mementukan kode tindakan. Selain itu, petugas koding hanya ada 2 orang.

Pelaksanaan koding yaitu dokumen yang akan dikoding dibagi menjadi dua yaitu koding untuk pasien umum dan BPJS Kesehatan. Koding pasien umum dilakukan setelah dokumen selesai pelayanan diassembling kemudian baru dilakukan proses koding dan indeksing, sedangkan untuk koding pasien BPJS Kesehatan dokumen setelah selesai pelayanan langsung dilengkapi berkas persyaratan dan langsung dikoding baru setelah itu diassembling dan indeksing. Penentuan diagnosa utama dan penyebab dasar kematian ditetapkan oleh dokter yang apabila ditemukan kesalahan atau inkonsistensi pencatatan diagnosa dapat melakukan klarifikasi kepada dokter penanggung jawab pelayanan.

Bagian unit indeksing melakukan kegiatan indeks secara komputerisasi yang terdapat pada SIRS rumah sakit yang sudah dijadikan satu dalam indeks penyakit sehingga mempercepat pengindeksan yang mana akan digunakan sebagai laporan penyakit maupun kebutuhan laporan lain yang membutuhkan data indeks.

Kinerja petugas koding dipengaruhi oleh faktor internal dan eksternal. Faktor internal antara lain motivasi (Surbakti, 2013; Asriyanto, 2013; Kusuma, 2013; Gardjito, Musadieq, dan Nurtjahjono, 2014; Tucunan, Supartha, dan Riana, 2014; Kharis, 2015; Apriani dan Hidayat, 2016; Moulana, Sunuharyo, dan Utami, 2017; dan Farizki, 2017), kepuasan dan kompetensi (Sajangbati, 2013; Rosita, 2016; dan Sukidi, 2017),. Faktor eksternal antara lain gaya kepemimpinan atasan (Sariadi, 2013; Sukwadi, 2014; dan Panjaitan, 2017; Surbakti, 2013; Tucunan, Supartha, dan Riana, 2014; Cahyono, Maarif, dan Suharjono, 2014; Subhi dan Yuniati, 2014; Handoko dan Djastuti, 2015; Kharis, 2015; dan Pambudi, Mukzam, dan Nurtjahjono, 2016), lingkungan kerja (Murdiyanto, 2012; Ginanjar, 2013; Asriyanto, 2013; Kusuma, 2013; Gardjito, Musadieq, dan Nurtjahjono, 2014; Budianto dan Katini, 2015; Kirana, Purwinarti, dan Onida, 2015; Apriani dan Hidayat, 2016; Pratama, 2016; Moulana, Sunuharyo, dan Utami, 2017; dan Farizki, 2017), sarana dan prasarana, dan kompensasi (Satedjo, 2017 dan Arifin, 2017).

Beberapa hal yang perlu diperhatikan dalam meningkatkan kinerja pegawai antara lain adanya motivasi yang tinggi, kompetensi yang memadai, kepemimpinan yang baik, dan adanya lingkungan kerja yang mendukung. Kinerja tinggi yang dimiliki oleh pekerja dapat menjadi sebuah keunggulan kompetitif bagi rumah sakit karena tidak dapat ditiru oleh pesaing rumah sakit. Dengan terbentuknya kinerja pegawai yang baik maka diharapkan perusahaan akan mampu bersaing dengan rumah sakit lain sehingga rumah sakit mampu diakui sebagai rumah sakit yang berkualitas.

Tujuan penelitian untuk mengetahui pelaksanaan dan kinerja petugas koding dan indeksing di RS Mitra Husada.

\section{Metode}

Peneliti menggunakan desain exploratory design atau strategi transformatif sekuential. Exploratory design adalah tahap awal metode menggunakan metode kuantitatif dan tahap berikutnya menggunakan metode kualitatif. Bobot metode lebih pada metode 
tahap kedua yaitu metode kualitatif dan selanjutnya dilengkapi dengan metode kuantitatif. Kombinasi data kedua metode bersifat connecting (menyambung) hasil penelitian tahap pertama (hasil penelitian kuantitatif) dan tahap berikutnya (hasil penelitian kualitatif) (Creswell and Clark, 2012). Dalam model ini peneliti memilih untuk menggunakan dua metode dalam penelitian yaitu kuantitatif dan kualitatif dengan partisipatif yaitu ada nilai kolaborasi antara peneliti dan partisipan.

Populasi adalah koding 100 kasus rawat inap di RS Mitra Husada. Sampel penelitian sebanyak 30 koding kasus rawat inap RS Mitra Husada. Pengumpulan data dilakukan dengan observasi terhadap dokumen rekam medis, wawancara dengan petugas koding dan indeksing RS Mitra Husada sebanyak 2 orang. Analisis data dilakukan dengan cara analisis kuantitatif dan kualitatif.

\section{Hasil}

\section{Pelaksanaan Koding dan Indeksing}

Berdasarkan analisa terhadap 30 kasus rawat ianp didapatkan presentase hasil analisis kesesuaian kode antara kode rumah sakit dan kode mahasiswa, yaitu :

$$
\begin{aligned}
& =\frac{\text { jumlah kode yang sesuai }}{\text { jumlah seluruh kasus }} \times 100 \% \\
& =\frac{30}{30} \times 100 \% \\
& =100 \%
\end{aligned}
$$

Persentase kesesuaian kode adalah $100 \%$. Selain kode diagnosa dan tindakan terdapat anamnesa, pemeriksaan baik fisik maupun penunjang dan lembar informed consent yang sesuai dan lengkap yang dapat menunjang diagnosa.

Bagian Indeksing di unit rekam medis Rumah Sakit Mitra Husada telah menjalankan tugas pokok dan fungsinya sesuai dengan analisa jabatan staf koding dan indeksing. Dalam melakukan kegiatan indeks penyakit secara komputerisasi yang terdapat pada SIRS rumah sakit dan dilakukan dengan cara mengentry data berupa nomor RM, ruang rawat, tanggal kunjungan, tanggal masuk, tanggal keluar, lama rawat, nama, jenis kelamin, umur, dokter, diagnose, kode ICD 10, dan operasi, kode tindakan ICD 9, keadaan waktu pulang dan cara keluar.
Setelah dientry kemudian disimpan, dimana indeks penyakit, indeks dokter, indeks operasi dan indeks kematian sudah dijadikan satu sehingga mempercepat pengindeksan yang mana akan digunakan sebagai laporan penyakit maupun kebutuhan laporan lain yang membutuhkan data indeks.

Formulir yang digunakan di Indeksing dalam pelayanan rekam medis :
a. Kartu kendali (KK)
b. Indeks penyakit
c. Indeks operasi
d. Indeks sebab kematian
e. Indeks dokter

Karena indeks dilakukan secara komputerisasi maka formulir manual seperti kertas indeks sudah tidak digunakan.

Kinerja Petugas Koding dan Indeksing

a. Man

1) Kurangnya sumber daya manusia bagian petugas koding dan indeksing namun petugas bisa berperan ganda menggantikan bagian petugas lain seperti pendaftaran yang menyebabkan terhambatnya proses koding maupun indeksing.

2) Petugas koding belum mengetahui adanya koding morbiditas berupa penggunaan Indeks MB dan penentuan sebab dasar kematian karena di Rumah Sakit Mitra Husada sudah ditentukan oleh dokter.

b. Method

Pelaksaan kegiatan yang tidak sesuai dengan SPO rumah sakit serta tidak adanya kejelasan dari mana dokumen diterima sebelum dikoding dan diindeks. Tercampurnya prosedur antara koding dan indeksing yang pada pelaksanaannya terpisah. Dalam pelaksanaan terdapat perbedaan koding antara pasien umum dan BPJS Kesehatan.

c. Machine

Tidak terdapat ICD elektronik yang dapat mempercepat proses pencarian diagnosa dan tindakan.

\section{Pembahasan}

\section{Pelaksanaan Koding dan Indeksing}

Bagian koding di unit rekam medis Rumah Sakit Mitra Husada telah menjalankan tugas pokok dan fungsinya sesuai dengan analisa jabatan staf 
koding dan indeksing. Kode diagnosa dan tindakan masih menggunakan ICD-10 dan ICD-9 CM secara manual tanpa menggunakan ICD elektronik secara komputerisasi serta terdapat buku pedoman singkatan yang dapat membantu dalam memahami singkatan medis di Rumah Sakit Mitra Husada.

Koder melakukan koding sesuai dengan langkah yang benar yaitu dengan memberi kode diagnosa dan tindakan yang ditulis oleh dokter dengan mencari kode diagnosa di buku ICD-10 Vol 3 dan setelah ditemukan dirujuk ke ICD-10 Vol 1, untuk tindakan medis atau operasi mencari kode di buku ICD-9 CM. Kemudian dituliskan pada lembar yang terdapat kode no ICD seperti lembar ringkasan masuk dan keluar serta lembar resume medis untuk kode rawat inap dan lembar ringkasan medis rawat jalan untuk kode rawat jalan. Dokumen yang akan dikode dibedakan antara pasien umum dan BPJS Kesehatan. Untuk koding pasien umum dilakukan setelah dokumen selesai pelayanan di assembling kemudian baru dilakukan proses koding dan indeksing, sedangkan untuk koding pasien BPJS Kesehatan dilakukan di ruangan BPJS Kesehatan, dokumen setelah selesai pelayanan langsung dilengkapi berkas persyaratan dan langsung dikoding baru setelah itu diassembling dan indeksing.

Pada Koding Morbiditas Proses koding dilakukan sesuai dengan diagnosis yang ditegakkan oleh dokter. Jika ditemukan kesalahan atau inkonsistensi pencatatan diangnosis, maka koder harus melakukan klarifikasi kepada dokter penanggungjawab pelayanan (DPJP). Pada koding pemeriksaan penunjang dan tindakan proses koding dilakukan sesuai dengan tindakan yang dilakukan oleh dokter. Jika ditemukan kesalahan atau inkonsistensi pencatatan tindakan, maka koder harus melakukan klarifikasi kepada dokter penanggungjawab pelayanan (DPJP). Pada koding kematian proses koding dilakukan sesuai dengan diagnosa termasuk penyebab kematian yang dianalisa dan ditulis oleh dokter sehingga petugas koding tidak melakukan analisa penyebab kematian dengan menggunakan indeks untuk kematian. Pada koding penyebab luar proses koding dilakukan terhadap kasus yang diperlukan untuk kepentingan seperti karena adanya kasus kecelekaan maka akan dikode sesuai dengan kejadian yang menyebabkan sesorang dirawat atau sakit. Kode dilakukan berdasarkan subyek dan obyek serta waktu terjadinya kejadian tersebut.

Bagian koding di Rumah Sakit Mitra Husada sudah memiliki kesesuaian kode yaitu sebesar 100\%.
Pelaksanaan koding petugas masih perlu belajar rule MB dan penyebab dasar kematian guna menambah pengetahuan petugas.

Pelaksanaan koding dan indeksing petugas dipengaruhi oleh motivasi, (Surbakti, 2013; Asriyanto, 2013; Kusuma, 2013; Gardjito, Musadieq, dan Nurtjahjono, 2014; Tucunan, Supartha, dan Riana, 2014; Kharis, 2015; Apriani dan Hidayat, 2016; Moulana, Sunuharyo, dan Utami, 2017; dan Farizki, 2017), kepuasan pegawai, dan kompetensi (Sajangbati, 2013; Rosita, 2016; dan Sukidi, 2017).

\section{Kinerja Petugas Koding dan Indeksing}

Man

1) Dilakukan penambahan sumberdaya manusia guna menunjang seluruh kegiatan termasuk koding dan indeksing.

2) Mempelajari koding morbiditas berupa penggunaan Indeks MB dan penentuan sebab dasar kematian guna menambah pengetahuan petugas yang apabila sewaktu-waktu dalam hal koder tidak berhasil melakukan klarifikasi kepada DPJP, maka koder menggunakan Indeks MB1 sampai MB5 untuk memilih kembali kode diagnosis utama ('re-seleksi'). Serta dapat menggunaan MMDS (Medical Mortality Data Sheet) dan pada bayi menggunakan indeks kematian perinatologi untuk menentukan penyebab dasar kematian yang apabila tidak berhasil melakukan klarifikasi kepada DPJP.

\section{Method}

Perlu dilakukan pembaharuan SPO yang lebih sesuai dengan pelaksanaan kegiatan saat ini. Menambahkan keterangan dari mana dokumen diterima dan prosedur yang menjelaskan perbedaan pelayanan pasien umum dan pasien BPJS Kesehatan.Serta pemisahan antara prosedur koding dan indeksing

\section{Machine}

Menyediakan ICD elektronik untuk mempercepat pencarian kode diagnosa karena kurangnya sumberdaya manusia.

Kinerja petugas koding dan indeksing dipengaruhi oleh faktor internal dan eksternal. Faktor internal antara lain motivasi (Surbakti, 2013; Asriyanto, 2013; Kusuma, 2013; Gardjito, Musadieq, dan Nurtjahjono, 2014; Tucunan, Supartha, dan Riana, 2014; Kharis, 2015; Apriani dan Hidayat, 2016; Moulana, Sunuharyo, dan Utami, 2017; dan Farizki, 
2017), kepuasan dan kompetensi (Sajangbati, 2013; Rosita, 2016; dan Sukidi, 2017).

Faktor eksternal antara lain gaya kepemimpinan atasan (Sariadi, 2013; Sukwadi, 2014; dan Panjaitan, 2017; Surbakti, 2013; Tucunan, Supartha, dan Riana, 2014; Cahyono, Maarif, dan Suharjono, 2014; Subhi dan Yuniati, 2014; Handoko dan Djastuti, 2015; Kharis, 2015; dan Pambudi, Mukzam, dan Nurtjahjono, 2016), lingkungan kerja (Murdiyanto, 2012; Ginanjar, 2013; Asriyanto, 2013; Kusuma, 2013; Gardjito, Musadieq, dan Nurtjahjono, 2014; Budianto dan Katini, 2015; Kirana, Purwinarti, dan Onida, 2015; Apriani dan Hidayat, 2016; Pratama, 2016; Moulana, Sunuharyo, dan Utami, 2017; dan Farizki, 2017), sarana dan prasarana, dan kompensasi (Satedjo, 2017 dan Arifin, 2017).

Kinerja petugas unit koding indeksing sudah terdapat SPO yang mana belum berjalan sesuai dengan pelaksanaan yang dilakukan petugas. Tercampurnya prosedur koding dan indeksing yang pada pelaksanaannya dilakukan secara terpisah sehingga mengindikasi ketidak patuhan petugas terhadap SPO yang terdapat di unit koding dan indeksing.

\section{Simpulan}

Bagian koding di Rumah Sakit Mitra Husada sudah memiliki kesesuaian kode yaitu sebesar 100\%. Pelaksanaan koding petugas masih perlu belajar rule MB dan penyebab dasar kematian guna menambah pengetahuan petugas. Kinerja petugas unit koding indeksing sudah terdapat SPO yang mana belum berjalan sesuai dengan pelaksanaan yang dilakukan petugas. Tercampurnya prosedur koding dan indeksing yang pada pelaksanaannya dilakukan secara terpisah sehingga mengindikasi ketidak patuhan petugas terhadap SPO yang terdapat di unit koding dan indeksing.

\section{Ucapan Terima Kasih}

Ucapan terima kasih ditujukan untuk pihak-pihak yang mempunyai kontribusi di dalam penelitian.

\section{Daftar Pustaka}

Apriani, D.R dan Hidayat, W. (2016). Pengaruh Lingkungan Kerja, Kepemimpinan, dan Motivasi Terhadap Kinerja Karyawan
PT. Kereta Api Indonesia (PERSERO) DAOP IV Semarang (Studi Pada PT.Kereta Api Indonesia Wilayah Kota Semarang). Jurnal Penelitian. Semarang: Jurusan Ilmu Administrasi Bisnis Fakultas Ilmu Sosial dan Ilmu Politik Universitas Diponegoro.

Arifin, M. (2017). Pengaruh Kompensasi Dan Kepuasan Kerja Terhadap Kinerja (Studi terhadap Fakultas Keguruan dan Ilmu Pendidikan Universitas Muhammadiyah Sumatera Utara). Jurnal EduTech Vol. 3 No. 2 September 2017. ISSN: 2442-6024. e-ISSN: 2442-7063. Medan: Fakultas Keguruan dan Ilmu Pendidikan Universitas Muhammadiyah Sumatera Utara.

Arikunto, S. (2016). Prosedur Penelitian Suatu Pendekatan Praktek. Jakarta: Rineka Cipta.

Asriyanto, N.A. (2013). Pengaruh Motivasi Kerja Dan Lingkungan Kerja Terhadap Kinerja Karyawan CV. Kalika Intergraha Di Semarang. Jurnal Penelitian. Semarang: Jurusan Fakultas Ekonomi Universitas Negeri Semarang.

Budianto, A.A.T dan Katini, A. (2015). Pengaruh Lingkungan Kerja Terhadap Kinerja Pegawai Pada PT Perusahaan Gas Negara (Persero) Tbk SBU Distribusi Wilayah I Jakarta. KREATIF. Jurnal Ilmiah Prodi Manajemen Universitas Pamulang. Vol. 3, No.1, Oktober 2015, hlm. 100-124.

Cahyono U.T., Maarif M.S., dan Suharjono. 2014. Pengaruh Kepemimpinan Transformasional Terhadap Kinerja Karyawan Di Perusahaan Daerah Perkebunan Jember. Jurnal Manajemen \& Agribisnis, Vol. 11 No. 2, Juli 2014, hlm. 68-76. Jember: Jurusan Produksi Pertanian Program Studi Produksi Tanaman Perkebunan Politeknik Negeri Jember.

Creswell, J.C and Clark, V.L.P. (2010). Designing and Conducting Mixed Methods Research. New York: SAGE Publications, Inc.

Farizki, M.R. (2017). Pengaruh Motivasi Kerja Dan Lingkungan Kerja Terhadap Kinerja Karyawan Medis. Jurnal Ilmu dan Riset Manajemen Volume 6, Nomor 5, Mei 2017, ISSN : 2461-0593. Surabaya: Sekolah Tinggi Ilmu Ekonomi Indonesia (STIESIA) Surabaya. 
Faik Agiwahyuanto, Tri Indah Sari, dan Shinta Octaviasuni. Analisis Ketepatan Koding Dan Kinerja ....

Gardjito A.H., Musadieq M.A., dan Nurtjahjono G.E. (2014). Pengaruh Motivasi Kerja Dan Lingkungan Kerja Terhadap Kinerja Karyawan (Studi Pada Karyawan Bagian Produksi PT. Karmand Mitra Andalan Surabaya). Jurnal Administrasi Bisnis (JAB). Vol. 13 No. 1 Agustus 2014. administrasibisnis. studentjournal.ub.ac.id. Malang: Fakultas Ilmu Administrasi Universitas Brawijaya.

Ginanjar, R.A. (2013). Pengaruh Lingkungan Kerja Terhadap Kinerja Karyawan Pada Dinas Pendidikan, Pemuda, Dan Olahraga Kabupaten Sleman. Jurnal Penelitian. Yogyakarta: Program Studi Manajemen Pendidikan Jurusan Administrasi Pendidikan Fakultas Ilmu Pendidikan Universitas Negeri Yogyakarta.

Handoko, A dan Djastuti, I. (2015). Pengaruh Kepemimpinan Transformasional Dan Motivasi Kerja Terhadap Kinerja Karyawan Dengan Kepuasan Kerja Sebagai Variabel Intervening (Studi pada PT. Kereta Api Indonesia (Persero) Daop 4 Semarang). DIPONEGORO JOURNAL OF MANAGEMENT Volume 4, Nomor 4, Tahun 2015, Halaman 1-13. http://ejournal-s1. undip.ac.id/index.php/dbr. ISSN (Online): 2337-3792.

Kharis, I. (2015). Pengaruh Gaya Kepemimpinan Transformasional Terhadap Kinerja Karyawan Dengan Motivasi Kerja Sebagai Variabel Intervening (Studi Pada Karyawan Bank Jatim Cabang Malang). Jurnal Administrasi Bisnis (JAB), Vol. 3 No. 1 Maret 2015, hlm. 1-9. administrasibisnis. studentjournal. ub.ac.id. Malang: Fakultas Ilmu Administasi Universitas Brawijaya.

Kirana, R.A., Purwinarti T, dan Onida, M. (2015). Pengaruh Lingkungan Kerja Terhadap Kinerja Karyawan Outsourcing Studi Pada Tower Management PT Indosat TBK. Epigram Vol. 12 No. 2 Oktober 2015, hlm. 127-132.

Kusuma, A.Adi. (2013). Pengaruh Motivasi Dan Lingkungan Kerja Terhadap Kinerja Karyawan Hotel Muria Semarang. Jurnal Penelitian. Semarang: Jurusan Fakultas Ekonomi Universitas Negeri Semarang.

Moulana, F, Sunuharyo B.S., dan Utami H.N. (2017). Pengaruh Lingkungan Kerja Terhadap Kinerja Karyawan Melalui Variabel Mediator
Motivasi Kerja (Studi pada Karyawan PT. Telkom Indonesia,Tbk Witel Jatim Selatan, Jalan A. Yani, Malang). Jurnal Administrasi Bisnis (JAB), Vol. 44 No.1 Maret 2017. administrasibisnis.studentjournal.ub.ac. id. hlm, 178-185. Malang: Fakultas Ilmu Administasi Universitas Brawijaya.

Murdiyanto, A. (2012). Analisis Pengaruh Motivasi Dan Lingkungan Kerja Terhadap Kinerja Karyawan Motor Hepy Cabang Jawa Tengah. Tema Vol 9 edisi 1, April 2012 hal. 12 - 28. Semarang: Fakultas Ekonomi Universitas Stikubank Semarang.

Pambudi D.S., Mukzam D, dan Nurtjahjono G.E. (2016). Pengaruh Gaya Kepemimpinan Transformasional Terhadap Kinerja Karyawan Melalui Kepuasan Kerja Karyawan Sebagai Variabel Mediasi (Studi pada Karyawan PT Telkom Indonesia Witel Jatim Selatan Malang). Jurnal Administrasi Bisnis (JAB), Vol. 39 No.1 Oktober 2016, hlm. 164-171. administrasibisnis.studentjournal.ub.ac. id. Malang: Fakultas Ilmu Administrasi Universitas Brawijaya.

Panjaitan, M. (2017). Pengaruh Gaya Kepemimpinan Dan Komunikasi Terhadap Kinerja Karyawan Pada PT. Putri Megah Asri Indah Medan. Jurnal Ilmiah Methonomi Vol. 3 No. 1 (Januari - Juni 2017). Jakarta: Program Studi Manajemen Fakultas Ekonomi Universitas Methodist Indonesia.

Pratama, A.N. (2016). Pengaruh Lingkungan Kerja Dan Disiplin Kerja Terhadap Kinerja Karyawan PT. Razer Brothers. Jurnal Penelitian. Yogyakarta: Program Studi Fakultas Ekonomi Universitas Negeri Yogyakarta.

Rosita, T. (2016). Pengaruh Kepuasan Kerja Terhadap Kinerja Karyawan Dengan Komitmen Organisasional Sebagai Variabel Intervening. Jurnal Ilmu dan Riset Manajemen: Volume 5, Nomor 1, Januari 2016. ISSN: 2461-0593. Surabaya: Sekolah Tinggi Ilmu Ekonomi Indonesia (STIESIA) Surabaya.

Sajangbati, I.A.S. (2013). Motivasi, Disiplin, dan Kepuasan Pengaruhnya Terhadap Kinerja Pegawai PT. Pos Indonesia (Persero) Cabang Bitung. Jurnal EMBA. Vol.1 No.4 Desember 2013, Hal. 667-678. Manado: Fakultas Ekonomi dan Bisnis, Jurusan Manajemen Universitas Sam Ratulangi Manado. 


\section{Sariadi, S. (2013). Gaya Kepemimpinan dan Motivasi Pengaruhnya Terhadap Kinerja Pegawai pada Bagian Sekretariat TNI AL Lantamal VIII di Manado. Jurnal EMBA. Vol.1 No.4 Desember 2013, Hal. 31-39. ISSN 2303-1174. Manado: Fakultas Ekonomi dan Bisnis, Jurusan Manajemen Universitas Sam Ratulangi Manado.}

Satedjo, A.D. (2017). Pengaruh Kompensasi Dan Disiplin Kerja Terhadap Kinerja Karyawan PT. Modern Widya Tehnical Cabang Jayapura. AGORA Vol. 5, No. 3, (2017). Surabaya: Program Studi Manajemen Bisnis Fakultas Ekonomi Universitas Kristen Petra.

Subhi, E.R dan Yuniati, T. (2014). Pengaruh Kepemimpinan Transformasional Terhadap Kinerja Karyawan Dengan Penghargaan Sebagai Variabel Moderating. Jurnal Ilmu \& Riset Manajemen Vol. 3 No. 2 (2014), hlm. 1-18. Surabaya: Sekolah Tinggi Ilmu Ekonomi Indonesia (STIESIA) Surabaya.

Sukidi. (2017). Pengaruh Motivasi, Kompensasi, dan Kepuasan Kerja Terhadap Kinerja Pegawai Dengan Kepuasan Kerja Sebagai Variabel
Intervening. Jurnal Ekonomi Manajemen Sumber Daya Vol. 18, No. 2, Desember 2016. Surakarta: Magister Manajemen Universitas Muhammadiyah Surakarta.

Sukwadi, R. (2014). Analisis Pengaruh Gaya Kepemimpinan dan Komunikasi Interpersonal Terhadap Kinerja Karyawan UKM. Jurnal Teknik dan Ilmu Komputer. Vol. 03 No. 11, Jul-Sep 2014. Jakarta: Program Studi Teknik Industri Universitas Katolik Atmajaya.

Surbakti, M.P. (2013). Analisis Pengaruh Kepemimpinan Transformasional \& Motivasi Terhadap Kinerja Karyawan (Studi pada PT. Kereta Api Indonesia Daop IV Semarang). Jurnal Penelitian. Semarang: Fakultas Ekonomi Universitas Diponegoro.

Tucunan R.J.A., Supartha W.G., dan Riana I.G. (2014). Pengaruh Kepemimpinan Transformasional Terhadap Motivasi dan Kinerja Karyawan (Sudi Kasus Pada PT. Pandawa). E-Jurnal Ekonomi dan Bisnis Universitas Udayana 3.9 (2014):533-550. ISSN : 2337-3067. Denpasar: Fakultas Ekonomi dan Bisnis Universitas Udayana. 